\title{
SANGGA BUWANA AS FOOD ACCULTURATION: YOGYAKARTA ROYAL TRADITIONAL FOOD
}

\author{
Marcellus Arnold ${ }^{\left(1,2^{*}\right)}$, Yolanda Victoria Rajagukguk ${ }^{(1,2)}$ \\ ${ }^{1}$ Faculty of Food Science and Nutrition, Poznań University of Life Sciences, Wojska Polskiego 31, 60-624 Poznań, Poland \\ ${ }^{2}$ Department of Nutrition and Food Technology, Faculty of Life Sciences, Surya University, Tangerang, Indonesia
}

\section{ARTICLE INFORMATION}

$\begin{array}{ll}\text { Submitted } & : 07^{\text {th }} \text { July } 2021 \\ \text { Review } & : 01^{\text {st }} \text { October } 2021 \\ \text { Accepted } & : 04^{\text {th }} \text { December } 2021 \\ \text { Published } & : 18^{\text {th }} \text { December } 2021 \\ \text { Available Online }: \text { December } 2021 .\end{array}$

\section{KEYWORDS}

Sangga buwana; Yogyakarta; Indonesia; traditional food; food acculturation.

\section{CORRESPONDENCE}

*E-mail: marcellus.arnold@up.poznan.pl

\begin{abstract}
A B S T R A C T
Indonesia has various traditional foods, some of which are the result of acculturation with other countries' foods. Sangga buwana is the JavaneseDutch influenced cuisine, which became one of the favorite dishes of the sultans of Yogyakarta. Till date, the publication about sangga buwana is still limited. This paper aimed to introduce and spread the knowledge about sangga buwana as the result of food acculturation, focusing on its history, philosophy, how it is prepared, and its nutritional value. The study was carried out through interviews with the experts and literature review. Sangga buwana consists of several components, including choux pastry, ragout, lettuce, boiled egg, Javanese mustard, and pickled vegetables. Sangga buwana itself and every component to prepare it have the meaningful philosophy about God's creations. It delivers important wishes and meanings to the newlywed couple in royal wedding ceremony. It was only served to the sultan, royal family of Yogyakarta, and their important guests. But nowadays, sangga buwana can be more easily found at restaurants, traditional markets or food festivals in Yogyakarta. The cultural preservation of sangga buwana has been conducted through cultural festivals, cooking workshops, and research development using local ingredients to prepare it which may support food diversification.
\end{abstract}

\section{A. INTRODUCTION}

ndonesia is a country with big diversity. Not only the cultures, the diversity also includes the various traditional foods from different regions (Kusumaningtyas \& Lestari, 2020). Traditional food in every ethnic group is influenced by the local culture and the local food commodities or sources in that region (Rajagukguk \& Arnold, 2021). Traditional food is the legacy of local tribe in specific region (Sabana, 2007), and an identity of a nation (Haruminori et al., 2017). It contributes in local people's life in providing nutrition and is also part of the community tradition, beliefs, social, and technology (Nutri, 2017). Indonesian traditional culinary is the cultural asset which must be preserved, so it would not become extinct as the modern cuisines from other countries are also developing nowadays (Harmayani et al., 2019b). With the traditional food diversity, it can be potential to promote Indonesian culinary tourism (Wijaya, 2019).
Yogyakarta, which is located in Java island (Fig. 1 ), is not only known as the city of education, but also as the center of the well-known Indonesian culinary culture (Harmayani et al., 2019a). Therefore, it can represent the Javanese traditional cuisines. Some of well-known traditional cuisines from Yogyakarta are gudeg (sweet jackfruit stew), brongkos (meat stew combined with tofu and blackeyed peas, cooked with coconut milk), pecel (mixed boiled vegetables, served with peanut sauce), geplak (sweet snack from grated coconut, rice flour, and sugar), wedang uwuh (herbal drink made from sappan wood, ginger, cloves, and cinnamon leaves), and wedang ronde (hot ginger drink with glutinous rice balls, bread, Arenga pinnata fruit, and roasted peanut) (Army, 2017; Harmayani et al., 2019a). Soto (Indonesian soupy dish, made from meat or vegetable broth with addition of shredded meat or chicken, vermicelli, bean sprouts, and other 
components), which can be found in every region in Indonesia, is also various from one region to another. Soto originated from Yogyakarta, such as chicken soto, Ngasem chicken soto, limpid soto, and beef soto is unique compared to other types of soto in Java or Indonesia (Yudhistira \& Fatmawati, 2020).

The Indonesian traditional food could be the original or authentic Indonesian cuisine, as well as the result of acculturation with other countries' cuisines (Rahman, 2016). The influence of eastern and western (especially European) culture on Indonesian cuisines, which are originally rich in spices, results in richer flavor and taste of cuisines (Gardjito et al., 2019). Indonesian traditional cuisines which have been influenced by Chinese culture are, but not limited to porridge, laksa (spicy noodle soup), pempek (savory fishcake, served with authentic sweet and sour sauce), bakso (Indonesian meatballs), siomay (steamed fish dumpling with vegetable and peanut sauce), soto, and wedang ronde (Gardjito et al., 2019; Harmayani et al., 2019a; Yudhistira \& Fatmawati, 2020). The Dutch, who colonized Indonesia for 350 years, also influenced Indonesian traditional cuisines, including croquette, nastar (pineapple tart), kastengel (cheese stick), and klappertaart (coconut cake) (Handoyo et al., 2018).

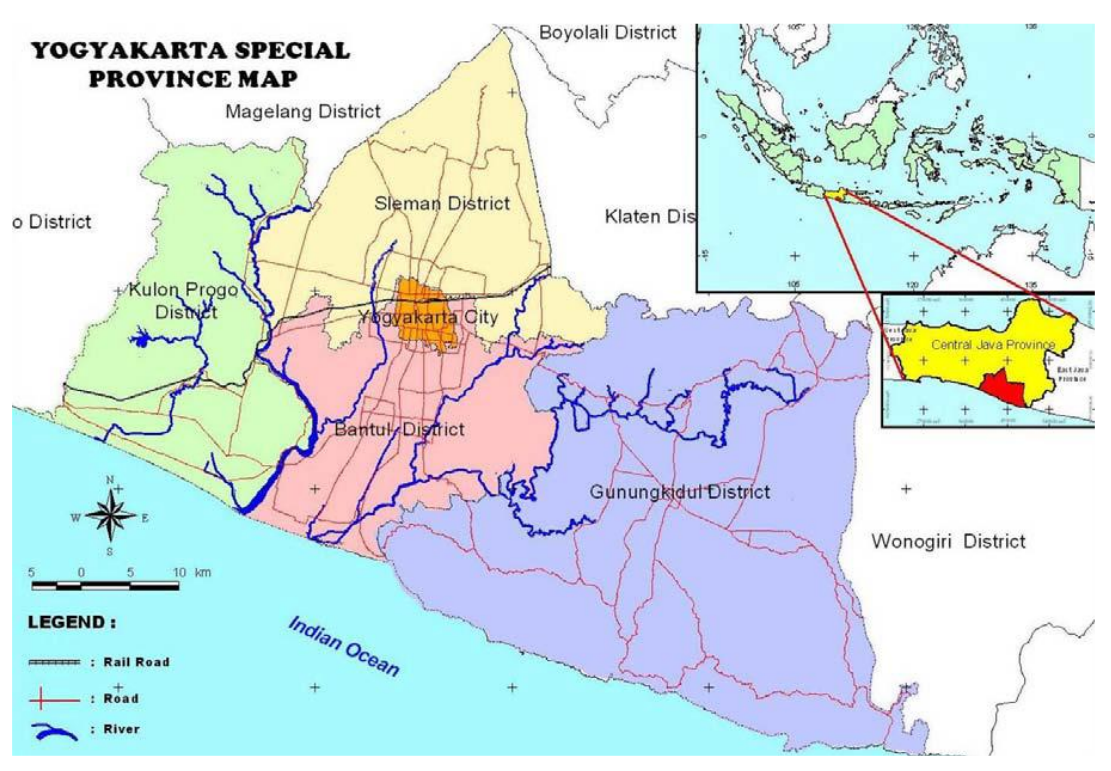

Figure 1.

Map of Special Region of Yogyakarta. Special Region of Yogyakarta is located on Java island of Indonesia, with Yogyakarta city (orange color) as the capital. Source: taken from (König et al., 2010).

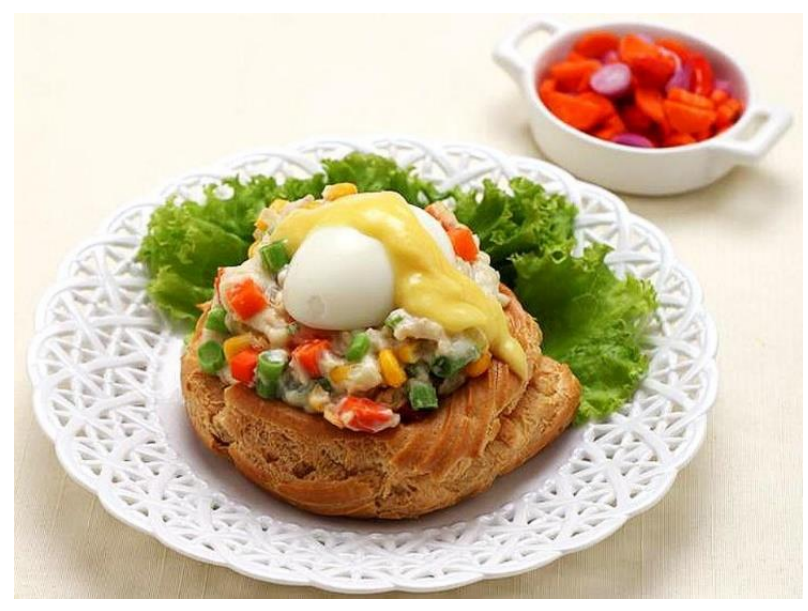

Figure 2.

Sangga buwana, the Javanese-Dutch influenced traditional dish. Source: adapted from (Primarasa, 2017).
Sangga buwana (Fig. 2), also known as songgo buwono, is also one of the Indonesian, especially Javanese traditional foods, acculturated by Dutch culture. Sangga buwana is originated from Yogyakarta, and was served only to the sultan of Yogyakarta and the royal family of Yogyakarta, as well as their important guests. So, not every person could serve and consume sangga buwana. Nowadays, sangga buwana can be consumed by everyone, and sometimes can be found at traditional markets or food festivals in Yogyakarta (Lestari et al., 2014). The favorite dishes of the sultans of Yogyakarta, especially Hamengkubuwono VII, Hamengkubuwono VIII, and Hamengkubuwono IX, were described by Gardjito et al. (Gardjito et al., 2010). Furthermore, some healthy traditional foods from Indonesia were also introduced by previous 
study (Harmayani et al., 2019a). However, till date, the publication focusing on sangga buwana, which was one of favorite dishes of the sultan of Yogyakarta is still limited. Therefore, this review aims to introduce and spread the knowledge about sangga buwana, including the history, philosophy, how it is prepared, and the nutrition facts. The authors hoped that this article could be useful for further research on sangga buwana, and could raise readers' awareness on sangga buwana as traditional food from Indonesia.

\section{B. METHOD}

$\mathrm{T}$ he interview was conducted to collect the information about history and philosophy of sangga buwana. The interviewees are the experts in the cultural and culinary studies, especially in the traditional foods and the Javanese (and Yogyakarta) history and literature. The interviewees were: 1) Prof. Dr. Ir. Murdijati Gardjito, author of books and articles about traditional foods, and professor of agricultural technology at Gadjah Mada University, Yogyakarta, Indonesia; 2) Drs. Wahjudi Pantja Sunjata, cultural researcher at Cultural Conservation Center in Yogyakarta (Balai Pelestarian Nilai Budaya Daerah Istimewa Yogyakarta), Indonesia; 3) Nur Wahyuni, S.Pd., M.Pd., lecturer and deputy director for academic affairs, Akademi Kesejahteraan Sosial - AKK Yogyakarta, Indonesia; 4) Prapto Yuwono, S.S., M.Hum., lecturer of Javanese literature, Faculty of Humanities, University of Indonesia, Depok, Indonesia. The interview was conducted in person, as well as by phone and email. Additionally, the literature review was also conducted in order to support the collected information from the interviewees.

\section{RESULTS AND DISCUSSION}

\section{History and Components of Sangga Buwana}

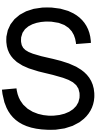
angga buwana is the traditional food resulted from the acculturation of Javanese and European culture. It is the choux pastry-based snack, filled with ragout (stewed minced meat), vegetables, and other components (Widya, 2018). The history of sangga buwana was initiated during the reign of Hamengkubuwono VII (1877 - 1921) (Fig. $3 A$ ), the seventh sultan of Yogyakarta. Hamengkubuwono VII had a preference in healthier traditional food with lower fat content (Budi et al., 1996). However, the main creation and development of sangga buwana was continued during the reign of his successor, Hamengkubuwono VIII (1921 - 1939) (Fig. 3B). During the reign of Hamengkubuwono VIII, as the sultan often invited the Dutch to the banquet, the presence of Dutch and their cultures influenced more the culture in the Yogyakarta Palace (Keraton Yogyakarta) (Budi et al., 1996). The art performance in the palace, such as traditional dance, was starting to use the new property such as sloki glass (a small glass for drinking liquor) and pistol, which were more modern property in that period, influenced by western culture. Besides the art performance, the menu or the dish served in the palace was also influenced more by western or Dutch culture, including the creation of sangga buwana. It was R. W. Hendrobudjono, who cooked and created sangga buwana. He was the leader of Pawon Prabeya, one of the palace kitchens to prepare daily dishes for sultan of Yogyakarta, especially Javanese cuisines with influence from European, and Dutch culture (Gardjito et al., 2017). Since then, sangga buwana became one of the favorite dishes of Hamengkubuwono VIII. The culture change, following the western culture, in the palace was done by Hamengkubuwono VIII with the purpose of political relation. Hamengkubuwono VIII intended to make a good relationship with the Dutch, and hoped that the conflict between his people and the Dutch could be quelled. It is worth noticing that at that time, it was almost impossible to fight against the Dutch colonialism (Budi et al., 1996).

Sangga buwana was only served among the priyayi (an elite class in Javanese tradition) and royal family in Yogyakarta Palace (Keraton Yogyakarta). It was also served to important guests in royal wedding. According to the interviewee, Gardjito, sometimes, the people who were still the relatives of royal family also served sangga buwana in wedding reception at the time that was not too close to daily meal times (breakfast, lunch, and dinner), for example at $9-10$ AM or 3 - 5 PM.

Nowadays, traditional markets or food festivals in Yogyakarta introduce sangga buwana to the public (Lestari et al., 2014). For example, sangga buwana could be found at Pasar Kangen Yogyakarta (or Pasar Kangen Jogja), which is the annual cultural festival, organized by government of Yogyakarta at Taman Budaya Yogyakarta (Fig. 4). In this cultural festival, the visitors can find various culinary cuisines and various kinds of old goods from the past, as well as enjoy the traditional art performances (Fatikasari, 2019). Sangga buwana and the other dishes from the Yogyakarta Palace can be also found in some restaurants in Yogyakarta, such as Bale Raos and Gadri Resto (Sholekhudin, 2016). 


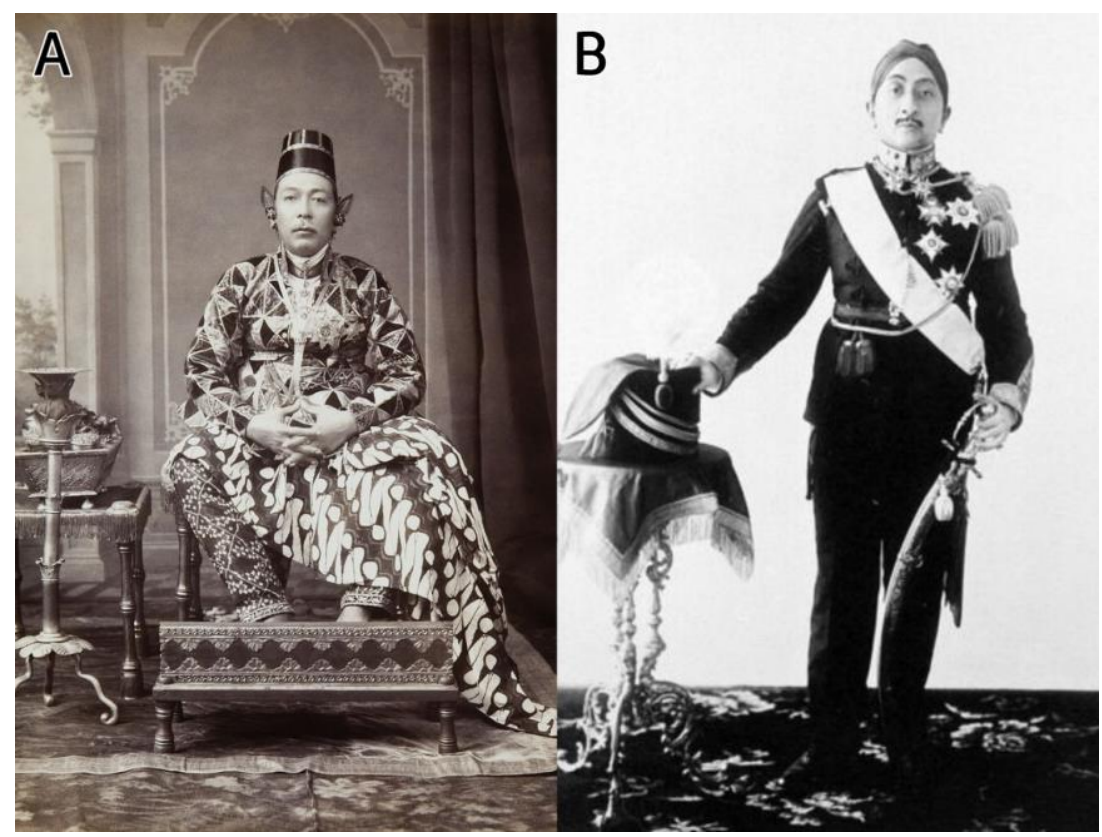

Figure 3.

The sultans of Yogyakarta: (A) Hamengkubuwono VII and (B) Hamengkubuwono VIII. The history of sangga buwana was initiated during the reign of Hamengkubuwono VII, continued and developed during the reign of Hamengkubuwono VIII. Source: adapted from Tropenmuseum, taken from en.wikipedia.org (CC BY-SA 3.0).

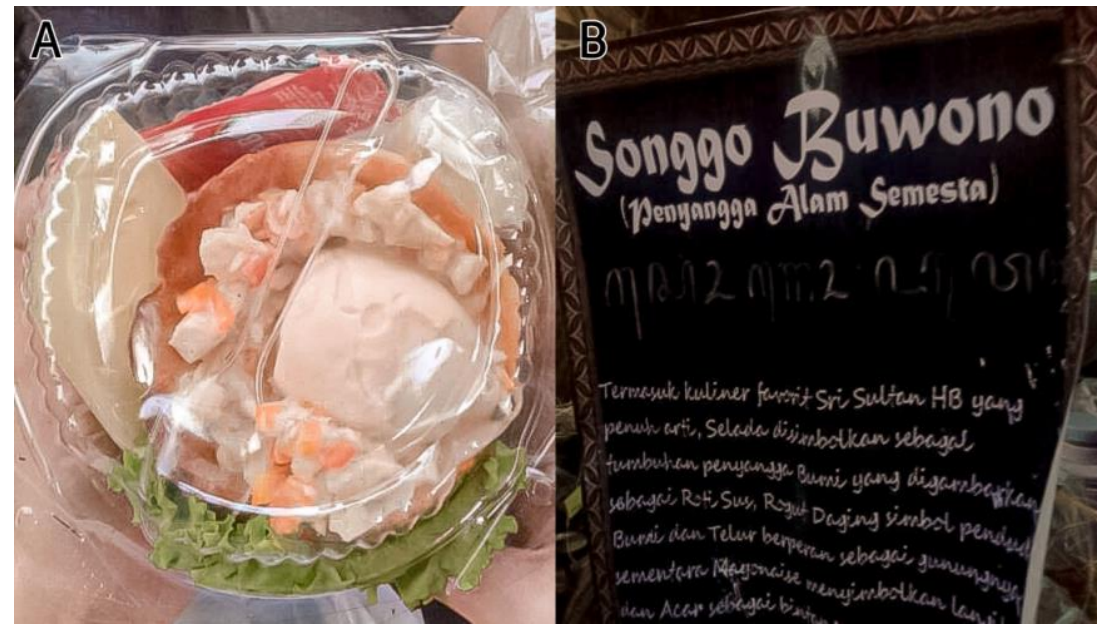

Figure 4.

(A) Sangga buwana was packed in convenient way using plastic packaging and was sold to the visitors at Pasar Kangen Yogyakarta. (B) The poster of sangga buwana (songgo buwono) with the explanation about its philosophy (in Indonesian language) was found in one of the food stalls at Pasar Kangen Yogyakarta to introduce the story behind this traditional food to the visitors. Source: authors' documentation at Pasar Kangen Yogyakarta in 2016.

There are three main parts or components in sangga buwana. First part is the choux pastry filled with ragout made from minced meat and vegetables. Second part is boiled chicken egg, which is cut into half to make the shape of parabola. This half boiled egg, complete with the white and yolk part, covers the top side of the choux pastry and ragout. This half boiled egg is covered by Javanese mustard on the top of it. Sometimes, the swan neck-shaped of choux pastry is added on the top of the egg. For the third part, other complements were added as the garnish, 215 | P a g e

https://doi.org/10.25077/jantro.v23.n2.p212-221.2021 including lettuce, and pickles (or acar) made from cucumber, carrot, pineapples, and sometimes shallot slices or bird's eye chili (Capsicum annuum) slices. The complete sangga buwana is then served on the plate, with a small fork to eat this sangga buwana.

\section{Philosophy of Sangga Buwana}

In the word "sangga buwana", "sangga" means to support, while "buwana" means the world or the life in the world. Thus, "sangga buwana" means to support the life in the world. In the wedding 
ceremony, where sangga buwana is served, it gives the meaning or wishes for the newlywed couple to be independent, so they can support their own life further.

Sangga buwana also symbolizes the human recognition of the power of God Almighty who created the world and everything in it. Every component in preparation of sangga buwana (Table 1) represents God's creations. The choux pastry represents the world; lettuce represents the plants and trees which hold and support the world; ragout symbolizes the people and the diversities in the world; boiled egg describes the mountains; Javanese mustard (or some sources mentioned mayonnaise) resembles the sky; and pickled vegetables represent the stars and everything fills the sky (Lestari et al., 2014). Therefore, when consuming sangga buwana, people will remember about everything that God has created for them. The varied tastes from these components, such as sour from pickles or Javanese mustard, and sweet and salty from ragout, also remind the newlywed couple that life is not always good or sweet, but also sometimes they will find difficulties and sorrow. The complete tastes obtained from sangga buwana also symbolize the various experiences which human may face during his life. But above all, everything is the gift from the God Almighty. So, this is how sangga buwana tells people about life.

From another point of view, especially from food acculturation point of view, sangga buwana could also be a symbol of diversity. The food acculturation, following the western or Dutch culture more often took place during the reign of the Sultan Hamengkubuwono VIII (Budi et al., 1996). The influence could be found in the ingredients of the dishes in the palace. For examples, the vegetables with the mayonnaise dressing, puddings, and cakes which represented the influence of western culture. In sangga buwana, from another point of view by the interviewee, Sunjata, the ingredients used to make sangga buwana (Table 1) also shows the symbol of acculturation from various countries and regions. The choux pastry is from the western culture, including the Dutch culture. As some sources also mentioned mayonnaise (as the substitute of Javanese mustard) in sangga buwana, it is also known that mayonnaise was from France, invented by Duke de Richelieu's chef in 1756 (Abd Rashed et al., 2017). There are also ragout from Asia and Europe countries, and pickles from Asia (Rajagukguk et al., 2016). Therefore, in a portion of sangga buwana, we can find the various cultures from different countries or regions. According to the interviewee, Yuwono,
Sangga buwana can also be interpreted as a symbol that the Sultanate of Yogyakarta was always be ready for the political situation changes due to the presence of the Dutch colonialism.

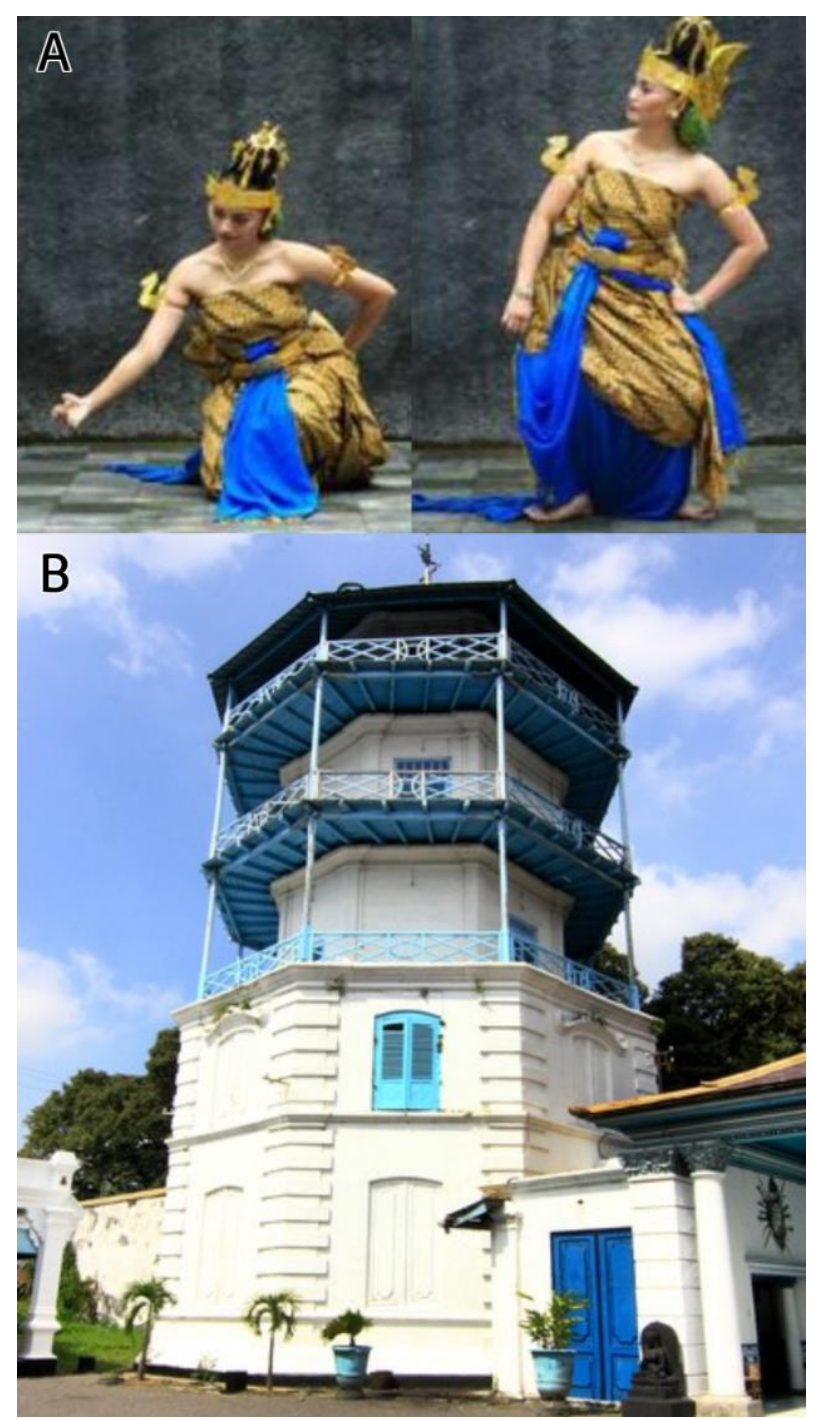

Figure 5.

Sangga buwana is also known in Surakarta (Solo), Indonesia. (A) Bedhaya Sangga Buwana traditional dance; photo source: (Karju et al., 2017). (B) Stage Sangga Buwana; photo source: (Indonesia Kaya, 2021). Both the traditional dance and the stage have the similar philosophy to sangga buwana as traditional food of Yogyakarta, Indonesia.

Yuwono also explained that the term "sangga buwana" is also known in Surakarta (also known as Solo), Central Java, Indonesia (Fig. 5). In Surakarta, instead of as the traditional food, sangga buwana is known as the name of a stage. The Stage Sangga Buwana (Fig. 5B) is the tower used by Surakarta Sultanate Palace, from which the sultan could meditate and communicate with the people, God, as well as Kanjeng Ratu Kencanasari (legendary figure in Java and Bali). It was built in $18^{\text {th }}$ century, during the reign of Pakubuwana III (Sawitri. 2021). This Stage Sangga Buwana also symbolizes the presence 
of the sultan to support the life of his people. The presence of sultan on this stage could be a reminder for the sultan himself to prosper his people. Sawitri (2021) reported that the utilization of the stage is based on the urgent matters faced by Surakarta Sultanate Palace. The stage can be used to deliver an apology to the respected spirits if one of the dancers of Bedhaya Ketawang is having her menstrual cycle. With the purpose of performing the Bedhaya dance successfully, the apology will be delivered in the form of flower offering and frankincense. Bedhaya is a classical Javanese dance originated from Surakarta Sultanate Palace. It is performed by women dancers from the palace during the sacred occasions.

Furthermore, the Surakarta Sultanate also recognizes traditional dance, named "Bedhaya Sangga Buwana" (Fig. 5A), inspired by the stage itself. The dance started with sowing the flowers with irregular dance moves that symbolizes selfpurification towards serenity (Sawitri. 2021). According to Karju et al. (2017), the dancers wear costumes with specific interpretation during Bedhaya Sangga Buwana traditional dance. The costumes include (1) dodot cloth with Parang Kusuma decoration symbolizes firmness and power, (2) blue shawl symbolizes graciousness and love, (3) greencolored hair ornament symbolizes fertility, (4) goldencolored decoration symbolizes successfulness, (5) jasmine strands symbolize chastity, (6) crown symbolizes the supreme ruler. The philosophy behind Bedhaya Sangga Buwana costumes is similarly related with the philosophy of sangga buwana food form Yogyakarta Sultanate. The main philosophy of Bedhaya Sangga Buwana traditional dance is the balance between mind, body and soul, as well as the harmony of life (Utami, 2017).

\section{Preparation of Sangga Buwana}

Table 1.

Components and ingredients to prepare sangga buwana

\begin{tabular}{ll}
\hline Components & Ingredients \\
\hline Choux pastry & $\begin{array}{l}\text { Wheat flour, water, margarine, } \\
\text { salt, sugar, eggs }\end{array}$ \\
Ragout & $\begin{array}{l}\text { Chicken or beef, carrot, onion, } \\
\text { pepper, water, wheat flour, salt, }\end{array}$ \\
& sugar \\
Javanese mustard & $\begin{array}{l}\text { Butter, egg yolk, wheat flour, } \\
\text { mustard, salt, sugar, lime juice } \\
\text { Complements }\end{array}$ \\
& $\begin{array}{l}\text { Lettuce, cucumber pickles (or } \\
\text { pickled vegetables), half boiled } \\
\text { egg }\end{array}$ \\
\hline \multicolumn{2}{c}{ Source: adapted from (Gardjito et al., 2017). }
\end{tabular}

There are various recipes found to prepare sangga buwana. But in general, the method of to prepare all the components of sangga buwana are described in Table 1. Those ingredients contributed to the complete nutritional value of sangga buwana (Table 2), which consists of carbohydrate (from wheat flour and sugar), protein (from chicken or beef preparing sangga buwana was described by Gardjito et al. (Gardjito et al., 2017). The ingredients needed and eggs), fat (from egg yolk, margarine, and butter), vitamins and minerals (from carrot, cucumber pickles, lettuce, lime juice, onion, pepper, salt, and other vegetables). 


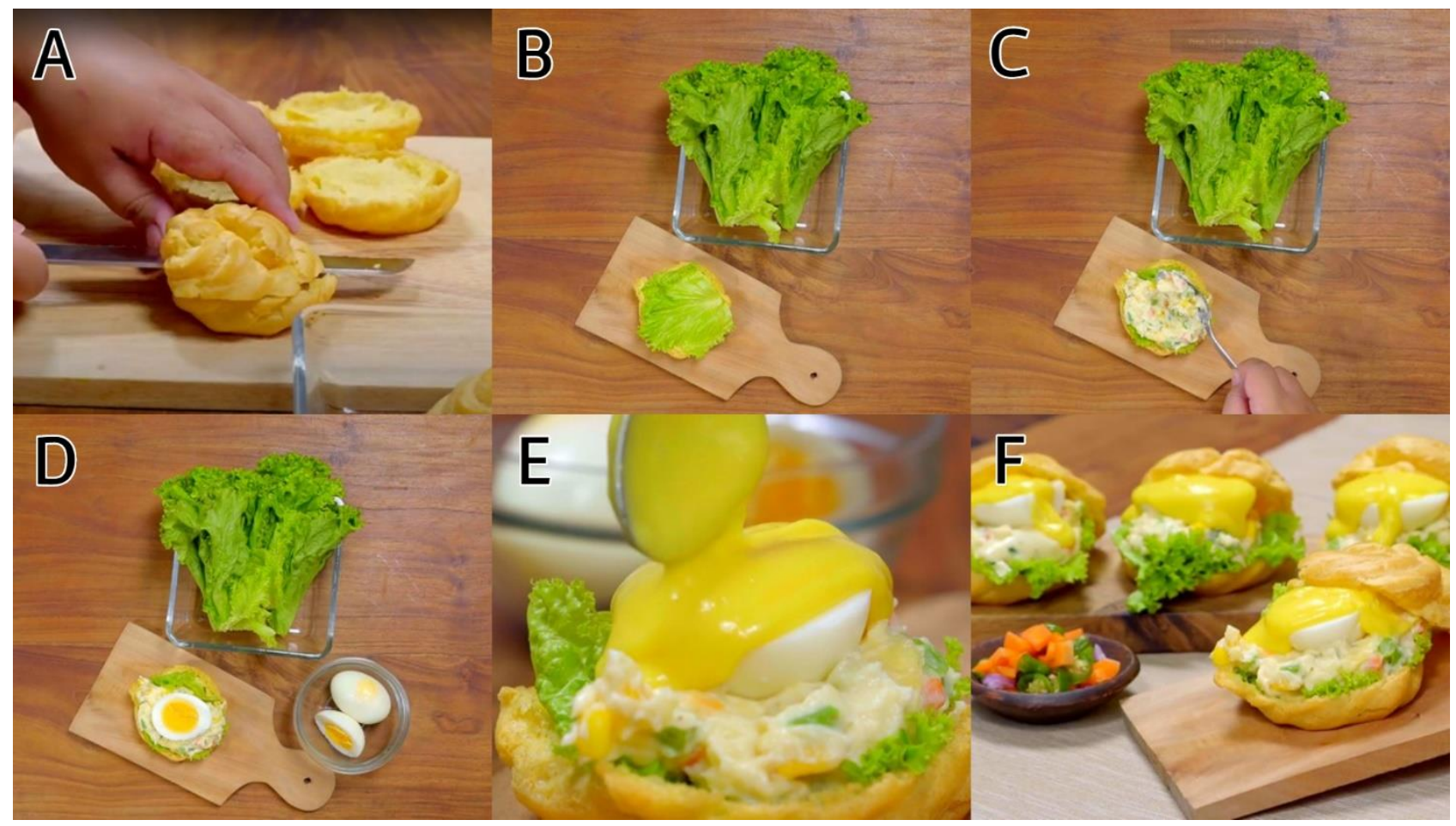

Figure 6.

Plating and garnishing of sangga buwana. (A) The choux pastry is cut into two sections. (B) Lettuce is put on the top of the choux pastry. (C) Ragout is added on the top of the lettuce. (D) Half boiled egg is added. (E) The Javanese mustard is added on the top of the half boiled egg. (F) Pickled vegetables are prepared on different plate and sangga buwana is ready to be served. The way of plating and garnishing of sangga buwana is similar to burger or sandwich. Source: adapted from (Tastemade Inc., 2020) with slight modification.

After all the components are prepared, plating and garnishing are conducted. The way of plating and garnishing of sangga buwana is also various, depends on the person who prepared it. The method of plating and garnishing of sangga buwana is shown in Fig. 6 (Tastemade Inc., 2020). Generally, the choux pastry is cut into two sections. The lettuce, ragout, and half boiled egg are then added between these sections. The Javanese mustard is then poured on the top of half boiled egg. The pickles are usually served on different plate. It is worth noticing that each component used to prepare sangga buwana has meanings and philosophy, described in section 2 .

\section{Nutrition Facts of Sangga Buwana}

Table 2.

Nutrition facts of sangga buwana per portion (65 g/portion)

\begin{tabular}{lr}
\hline Energy value (kcal) & 167.63 \\
\hline Fat $\mathbf{( g )}$ & 10.23 \\
\hline Carbohydrate (g) & 12.57 \\
\hline Protein $\mathbf{( g )}$ & 6.32 \\
\hline Water $\mathbf{( g )}$ & 35.14 \\
\hline Minerals (g) & 0.74
\end{tabular}

Source: adapted from (Lestari et al., 2014).
The information about nutrition facts of one portion of sangga buwana is shown in Table 2 (Lestari et al., 2014). Sangga buwana can be categorized as one dish meal, just like burger or sandwich, and consists of carbohydrate from the choux pastry, protein and fat from meat in ragout and egg, and vitamins and minerals from the pickled vegetables and lettuce (Arnold et al., 2017; Lestari et al., 2014). The complete nutrients found in sangga buwana, such as carbohydrate, protein, and fat which contribute to moderate energy value, make it consumed without any addition or supplementation. However, the small portion of sangga buwana (65 $\mathrm{g} /$ portion) makes it consumed as a snack, instead of a main dish in breakfast, lunch, or dinner (Lestari et al., 2014). Besides its complete nutrients, sangga buwana is also prepared freshly, without any addition of food preservatives. Therefore, it can be an option of a healthier dish.

\section{Sangga Buwana from Time to Time}

Following the social and economic situation changes from time to time, the modifications of sangga buwana have taken place, especially in its ingredients and recipe. For examples, the substitution of beef with chicken as the main ingredient of ragout of sangga buwana. Furthermore, 
the utilization of local commodities as the substitute of the ingredients have been conducted to support food diversification. The potency of breadfruit flour (Artocarpus altilis) as the substitute of wheat flour to make choux pastry of sangga buwana was also reported (Arnold et al., 2017). Food diversification using local ingredients could be the way to change and improve people's consumption patterns as well as to improve the nutritional quality of the product (Amanto et al., 2019). Food diversification in traditional foods could also support the local farmers (FAO, 2012; Gillespie et al., 2007). The development of sangga buwana is still open till date. Furthermore, according to the interviewee, Wahyuni, the way of serving the sangga buwana also sometimes changes, such as the addition of emping (chips made from melinjo (Gnetum gnemon) seeds) to improve the taste of sangga buwana. As one of the efforts to preserve the culture, the introduction of sangga buwana through cooking workshop was conducted at Presidential Palace, Yogyakarta in 2018 (Widya, 2018).

\section{CONCLUSIONS}

$\mathrm{T}$ he Dutch colonization impacted positively in acculturation of traditional foods in Indonesia, for example in Yogyakarta. Sangga buwana is one of them, which became one of the favorite dishes of Hamengkubuwono VIII. The philosophy of sangga buwana is related to God's creations and food acculturation. It also delivers the message to the newlywed couple to be independent and could support their own life after marriage. Due to the meaningful philosophy behind the creation of sangga buwana, people nowadays need to preserve this traditional food. Some of the ways of cultural preservation of sangga buwana were conducted, including cooking workshop and annual cultural festival at Pasar Kangen Yogyakarta. Furthermore, food diversification by using local ingredients, such as breadfruit flour as the substitute ingredient of wheat flour could be potential to develop the production of sangga buwana. Further studies on sangga buwana in various aspects could be carried out according to the information and knowledge from this article.

\section{E. ACKNOWLEDGMENT}

$\mathrm{T}$ he authors would like to express sincere gratitude to the interviewees: Prof. Dr. Ir. Murdijati Gardjito from Gadjah Mada University, Yogyakarta, Indonesia; Drs. Wahjudi Pantja Sunjata from Cultural Conservation Center in Yogyakarta (Balai Pelestarian Nilai Budaya Daerah Istimewa Yogyakarta), Indonesia; Nur Wahyuni, S.Pd., M.Pd. from Akademi Kesejahteraan Sosial AKK Yogyakarta, Indonesia; Prapto Yuwono, S.S., M.Hum. from University of Indonesia, Depok, Indonesia, for their valuable information and contribution in this article. The authors also would like to thank Emely, Rio Lawandra, Tri Oktaviani, and Dr. Albert Kuhon from Department of Nutrition and Food Technology, Faculty of Life Sciences, Surya University, Tangerang, Indonesia.

\section{REFERENCES}

Abd Rashed, A., Md Noh, M. F., Khalid, N. M., Ab Rahman, N. İ., Tasirin, A., Omar, W. S. W., Nawi, M. N. M., Jamilan, M. A., \& Selamat, R. (2017). The nutritional composition of mayonnaise and salad dressing in the Malaysian market (Komposisi pemakan mayonis dan kuah salad dalam pasaran Malaysia). Sains Malaysiana, 46 (1), 139-147. doi: http://dx.doi.org/10.17576/ism-2017-4601-18

Amanto, B. S., Umanailo, M. C. B., Wulandari, R. S., Taufik, T., \& Susiati, S. (2019). Local consumption diversification. International Journal of Scientific and Technology Research, 8 (8), 1865-1869.

Army, R. (2017). Kuliner Yogyakarta, Cerita di Balik Nikmatnya (S. Untoro (ed.)). Jakarta: National Agency for Language Development and Books, Ministry of Education and Culture of Indonesia.

Arnold, M., Lawandra, R., Rajagukguk, Y. V., Oktaviani, T., \& Emely, E. (2017). Potensi "Sangga Buwana" dengan substitusi tepung sukun sebagai makanan siap saji yang sehat. Nutri-Sains, 1 (1), 1-11. doi: http://dx.doi.org/10.21580/ns.2017.1.1.1130

Budi, N. S., Adrianto, A., Mudijono, Sumarno, \& Maharkesti, S. A. (1996). Tradisi Makan dan Minum di Lingkungan Kraton Yogyakarta (N. Kasniyah (ed.)). Yogyakarta: Departemen Pendidikan dan Kebudayaan Daerah Istimewa Yogyakarta.

Fatikasari, R. (2019). Indonesia Tempo Dulu Kembali Hadir di Pasar Kangen Yogyakarta. Available online from: https://www.goodnewsfromindonesia.id/2019/07/22/pasar-kangen-yogyakarta [Accessed on June 6, 2021]. 
FAO (Food and Agriculture Organization of the United Nations). (2012). Traditional foods, nutrition education key to fighting hunger and malnutrition. Available online from: https://www.fao.org/news/story/en/item/159244/icode/ [Accessed on November 4, 2021].

Gardjito, M., Harmayani, E., \& Santoso, U. (2019). Makanan Tradisional Indonesia Seri 3 - Makanan Tradisional yang Populer: Menu Sepiring Lengkap dan Makanan Berbasis Buah-Buahan. Yogyakarta: Gadjah Mada University Press.

Gardjito, M., Indrati, R., \& Amaliah. (2010). Menu Favorit Para Raja (Victi (ed.)). Yogyakarta: Kanisius.

Gardjito, M., Nindyarani, A. K., Putri, R. G., \& Chayatinufus, C. (2017). Kuliner Yogyakarta - Pantas Dikenang Sepanjang Masa (I. Hardiman (ed.)). Jakarta: PT. Gramedia Pustaka Utama.

Gillespie, G., Hilchey, D. L., Hinrichs, C. C., \& Feenstra, G. (2007). Farmer's markets as keystones in rebuilding local and regional food systems. In C. C. Hinrichs \& T. A. Lyson (Eds.), Remaking the North American Food System: Strategies for Sustainability (pp. 65-83). Lincoln: University of Nebraska Press.

Handoyo, C. C., Clarissa, Claudia, G., Milka, \& Firdayanti, S. A. (2018). Klappertaart: an Indonesian-Dutch influenced traditional food. Journal of Ethnic Foods, 5 (2), 147-152. doi: http://dx.doi.org/ 10.1016/i.jef.2017.12.002

Harmayani, E., Anal, A. K., Wichienchot, S., Bhat, R., Gardjito, M., Santoso, U., Siripongvutikorn, S., Puripaatanavong, J., \& Payyappallimana, U. (2019a). Healthy food traditions of Asia: Exploratory case studies from Indonesia, Thailand, Malaysia, and Nepal. Journal of Ethnic Foods, 6 (1), 1-18. doi: http://dx.doi.org/10.1186/s42779-019-0002-x

Harmayani, E., Santoso, U., \& Gardjito, M. (2019b). Makanan Tradisional Indonesia Seri 1 - Kelompok Makanan Fermentasi dan Makanan yang Populer di Masyarakat. Yogyakarta: Gadjah Mada University Press.

Haruminori, A., Angelia, N., \& Purwaningtyas, A. (2017). Makanan etnik Melayu: Tempoyak. Jurnal Antropologi: Isu-Isu Sosial Budaya, 19 (2), 125-128. doi: http://dx.doi.org/10.25077/jaisb.v19.n2.p125-128.2017

Indonesia Kaya. 2021. Keraton Surakarta, Pusat Pemerintahan di Masa Lalu. Available online from: https://indonesiakaya.com/pustaka-indonesia/keraton-surakarta-pusat-pemerintahan-di-masa-lalul [Accessed on November 5. 2021].

Karju, K., Utami, H. E., Supriyanto, E. (2017). Penciptaan Tari Bedaya Sangga Buwana. Prosiding: Seni, Teknologi dan Masyarakat, 2.

König, H. J., Schuler, J., Suarma, U., McNeill, D., Imbernon, J., Damayanti, F., Aini, S. D., Uthes, S., Sartohadi, J., Helming, K., \& Morris, J. (2010). Assessing the impact of land use policy on urban-rural sustainability using the FoPIA approach in Yogyakarta, Indonesia. Sustainability, 2 (7), 1991-2009. doi: http://dx.doi.org/10.3390/su2071991

Kusumaningtyas, M., \& Lestari, S. (2020). Model pengembangan makanan dan pariwisata halal di Indonesia. Media Mahardhika, 19 (1), 44-49. doi: http://dx.doi.org/10.29062/mahardika.v19i1.195

Lestari, L. A., Sari, P. M., \& Utami, F. A. (2014). Kandungan Zat Gizi Makanan Khas Yogyakarta. Yogyakarta: Gadjah Mada University Press.

Nurti, Y. (2017). Kajian dalam perspektif antropologi. Jurnal Antropologi: Isu-Isu Sosial Budaya, 19 (1), 1-10. doi: http://dx.doi.org/10.25077/jantro.v19.n1.p1-10.2017

Primarasa. $\quad$ (2017). Songgo Buwhono Sayuran. Available online from: https://www.primarasa.co.id/camilan/songgo-buwhono-sayuran [Accessed on June 6, 2021].

Rahman, F. (2016). Rijsttafel: Budaya Kuliner di Indonesia Masa Kolonial 1870-1942 (C. Hardjono \& W. Retna (eds.)). Jakarta: PT. Gramedia Pustaka Utama.

Rajagukguk, Y. V., \& Arnold, M. (2021). Tempoyak: Fermented durian paste of Malay ethnic and its functional properties. International Journal of Gastronomy and Food Science, 23, 100297. doi: http://dx.doi.org/10.1016/i.ijgfs.2020.100297

Rajagukguk, Y. V., Arnold, M., Oktaviani, T., Emely, \& Lawandra, R. (2016). Sangga Buwana - Makanan Priyayi dari Keraton Yogyakarta. Available online from: https://budaya-indonesia.org/Sangga-BuwanaMakanan-Priyayi-dari-Keraton-Yogyakarta [Accessed on November 4, 2021].

Sabana, S. (2007). Nilai estetis pada kemasan makanan tradisional Yogyakarta. ITB Journal of Visual Art and Design, 1(1), 10-25.

Sawitri. (2021). Tari Bedhaya dan Bedhayan: Kajian ideologis dan historis (Andriyanto (ed)). Klaten: Penerbit Lakeisha.

Sholekhudin, M. (2016). Wisata Jajan Yogyakarta. Jakarta: Penerbit Majalah Intisari.

Tastemade Inc. (2020). Songgo Buwono (Egg Benedict Ala Keraton). Available online from: https://id.tastemade.com/videos/songgo-buwono [Accessed on July 1, 2021].

Utami, H. E. (2017). Karya Seni Tari Bedhaya Sangga Buwana. Surakarta: Faculty of Performance Arts, Institut Seni Surakarta.

Widya, K. (2018). Cerita Kehidupan Manusia dalam Menu Songgo Buwono. Available online from: https://www.setneg.go.id/baca/index/cerita kehidupan manusia dalam menu songgo buwono [Accessed on July 1, 2021]. 
Wijaya, S. (2019). Indonesian food culture mapping: a starter contribution to promote Indonesian culinary tourism. Journal of Ethnic Foods, 6 (9), 1-10. doi: http://dx.doi.org/10.1186/s42779-019-0009-3

Yudhistira, B., \& Fatmawati, A. (2020). Diversity of Indonesian soto. Journal of Ethnic Foods, 7 (27), 1-9. doi: http://dx.doi.org/10.1186/s42779-020-00067-z 